\title{
APLICAÇÃO DA METODOLOGIA 5S NA MANUTENÇÃO: ESTUDO DE CASO EM UMA EMPRESA DE TRATAMENTO E BENEFICIAMENTO DE PELE BOVINA - CURTUME
}

\author{
Congresso Nacional Online de Empreendedorismo, 3a edição, de 06/12/2021 a 08/12/2021
} ISBN dos Anais: 978-65-81152-30-7

PIOVESAN; Gleice Copodê ${ }^{1}$, SILVA; Danilo Santiago 2, SANTOS; Italo Coutinho dos ${ }^{3}$, CHIME; Darlan Oliveira ${ }^{4}$, SILVÉRIO; Adriano Serra ${ }^{5}$

\section{RESUMO}

O método $5 \mathrm{~S}$ originário da Japão, desde que foi estabelecido no país brasileiro, apresenta como finalidade no mesmo sentido auditar ambientes, os quais necessitam de cuidados organizacionais, e aqueles cujo, que regem grande fluxo do trabalho de vários colaboradores,como indústrias, empresas, fábricas, entre outras. No seu país de origem, este método auxiliou de forma fundamental a organização das cidades no pósguerra, retomando as atividades,trabalhos, e a organização empresarial propriamente dita. No Brasil, o método 5S é difundido principalmente em empresas do ramo industrial, as quais necessitam de um grande fluxo de colaboradores e turnos. O principal objetivo deste método, é realizar de forma simples o atendimento a alguns métodos que proporcionem uma série de vantagens para o ambiente,seguido de métodos, sendo 5: Seiri; Seiton; Seiso; Seiketsu e Shituske, os quais traduzidos para o português, configuram: Utilização; Organização; Limpeza; Conservação e Disciplina, respectivamente. Entretanto, existem alguns desafios quanto a implantação propriamente dita deste conceito na prática, principalmente pela falta do entendimento, conhecimento e aplicação do método por colaboradores e a população como um todo, Esse método promove algumas vantagens, como a qualidade de vida, padronização de procedimentos, gestão da qualidade, reutilização e conservação de materiais entre outros. Desta forma, o presente trabalho, buscou avaliar, através de um estudo qualitativo e quantitativo, a eficiência e o relacionamento com o método de colaboradores de uma empresa do ramo industrial, denominada na análise como Curtume de Nova Andradina - MS, localizada no mesmo município. Foi empregado o uso de questionário aplicado, e o registro de fotos dos relatos de antes e depois a aplicação do método $5 \mathrm{~S}$ no setor da manutenção da empresa. A fim de relacionar os parâmetros encontrados na pesquisa foram utilizados também os métodos bibliográfico e exploratório, para entendimento, compreensão e a geração de novas conclusões sobre o assunto. Pode-se concuir que onde o método 5S, foi bem aceito pelos colaboradores de um determinado setor e após a interpretação das respostas ficou evidenciado que todos ( $100 \%$ da amostra) positivaram quanto a melhoria em geraldo setor. O principal objetivo com a implantação do programa foi a facilitar o trabalho e reduzir de tempo na procura de peças. Pode-se verificar que o objetivo foi atingido após as observações realizadas.

PALAVRAS-CHAVE: Padronização, Engenharia de Produção, Método 5S, 
